\title{
MORTGAGE
}

INDEBTEDNESS

AND HOUSEHOLD

FINANCIAL

DISTRESS

by Dimitris Georgarakos,

Adriana Lojschova and

Melanie Ward-Warmedinger 


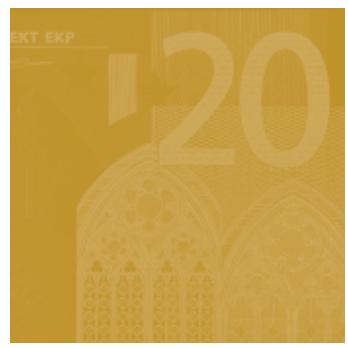

\title{
WORKING PAPER SERIES
}

NO II56 / FEBRUARY 2010

\section{MORTGAGE INDEBTEDNESS AND HOUSEHOLD FINANCIAL DISTRESS '}

\author{
by Dimitris Georgarakos ${ }^{2}$, Adriana Lojschova ${ }^{3}$, \\ and Melanie Ward-Warmedinger ${ }^{4}$
}

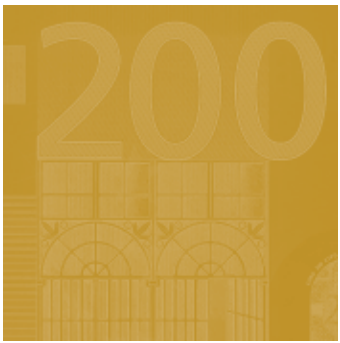

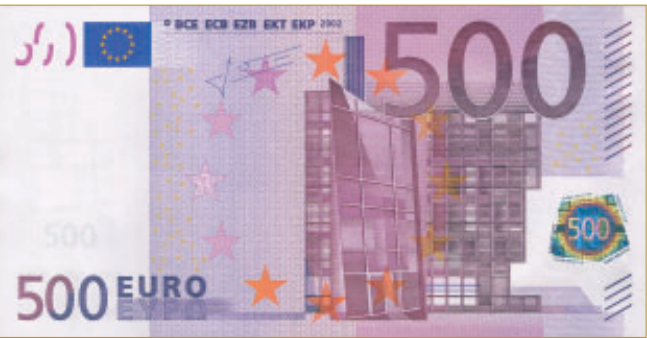

In 2010 all ECB publications feature a motif taken from the $€ 500$ banknote.
This paper can be downloaded without charge from http://www.ecb.europa.eu or from the Social Science Research Network electronic library at http://ssrn.com/abstract_id $=1456593$.

I We are grateful to Carol Bertaut, Olympia Bover, Michael Ehrmann, Michael Haliassos, Tullio Jappelli, Arthur Kennickell, Huw Pill, Jiri Slacalek, Kostas Tatsiramos, Thomas Westermann and especially Dimitris Christelis and Raffaele Miniaci for very helpful suggestions and comments. We also like to thank participants at the European Economic Association Annual Congress in Barcelona and at the research seminars of the Monetary Policy Stance Division and the Household Finance and Consumption Network at the ECB and at the Economics Department at the University of Brescia. Georgarakos acknowledges financial support by the Center for Financial Studies (CFS) under the Research Program 'Household Wealth Management'. 2 Corresponding author: Goethe University Frankfurt, House of Finance, Grüneburgplatz I, PF H32, D-60323 Frankfurt am Main, Germany and CFS; e-mail: georgarakos@wiwi.uni-frankfurt.de 3 European Central Bank, Kaiserstrasse 29, 603II Frankfurt am Main, Germany and IMF, Washington; e-mail: adriana.lojschova@ecb.europa.eu 


\section{(C) European Central Bank, 2010}

Address

Kaiserstrasse 29

60311 Frankfurt am Main, Germany

Postal address

Postfach 160319

60066 Frankfurt am Main, Germany

Telephone

+496913440

Website

http://www.ecb.europa.eu

Fax

+496913446000

All rights reserved.

Any reproduction, publication and reprint in the form of a different publication, whether printed or produced electronically, in whole or in part, is permitted only with the explicit written authorisation of the ECB or the author(s).

The views expressed in this paper do not necessarily reflect those of the European Central Bank.

Information on all of the working papers published in the ECB's Working Paper Series can be found on the ECB's website, http://www.ecb.europa.eu/pub/scientific/ wps/date/html/index.en.html

ISSN 1725-2806 (online) 


\section{CONTENTS}

Abstract

Non-technical summary

1 Introduction

2 Home ownership rates and mortgage markets in Europe

3 Which factors contribute to financial distress among mortgage holders?

3.1 General framework

3.2 Model specification

3.3 Discussion of results

4 The role of relative mortgage indebtedness

5 Cross country differences in institutions and household beliefs about debt

5.1 The efficiency of contract enforcement

5.2 Changes in housing prices

5.3 The role of credit institutions

5.4 National differences in household views about debt and in response style

6 Conclusions

References

Tables and figures

Appendix 


\begin{abstract}
Using comparable survey data from twelve European countries from 1994 to 2001 we investigate households' attitudes towards mortgage indebtedness. We find that a given debt burden creates much higher distress in countries with fewer mortgage holders relative to countries where a significant part of households uses mortgage debt. This effect is net of ppp-adjusted income levels, various socioeconomic characteristics, housing traits, country-specific constant terms, and household unobserved heterogeneity. We show that households evaluate their own debt burden partly in comparison with the debt position of their peer group and in a way consistent with social stigma considerations which lessen in significance as markets expand.
\end{abstract}

JEL classification: D12, D14, G21

Keywords: Mortgage debt, credit markets, financial distress, household finance, peer effects 


\section{Non-technical summary}

Using comparable survey data from twelve European countries from 1994 to 2001 we investigate households' attitudes towards mortgage indebtedness. We find that a given debt burden creates much higher distress in countries with fewer mortgage holders relative to countries where a significant part of households uses mortgage debt. This is the case after taking into account ppp-adjusted income levels, a rich set of socioeconomic characteristics, housing traits, country-specific constant terms, and household unobserved heterogeneity. We attribute part of this asymmetry to cross-country differences in the expansion of credit markets, which facilitate differential access to liquidity. Household's reported distress is also affected by excess indebtedness relative to the debt load of reference households, and crucially so in countries with less expanded mortgage markets. Thus it appears that households evaluate their own debt burden partly in comparison with the debt position of their peer group and in a way consistent with social stigma considerations which lessen in significance as markets expand. Households' assessment of a debt burden therefore tends to diminish in more expanded credit markets and this process can be reinforced by reference to other households in a growing pool of debt holders. 


\section{Introduction}

Households' borrowing decisions are important, for their own well-being and for aggregate consumption, asset demand and financial stability. In recent years, households have experienced a rapid expansion of credit markets and may have been encouraged by the financial sector to take out mortgages and consumer loans. Problems start to arise when households borrow amounts that are disproportional to their means. During unfavourable macroeconomic conditions, where unemployment rates rise and household assets depreciate in value, such a tendency may result in an inability to pay off loans. At the same time, the market loses confidence in assets that have been used to secure such loans and the setbacks incurred can be traced back as one of the main sources of the recent financial crisis. Thus, understanding the conditions that shape households' borrowing behaviour is of key importance.

Domestic property is the dominant asset category in household portfolios, especially in Europe. On the liability side, mortgages typically represent the largest debt burden. ${ }^{1}$ Home ownership rates are particularly high in Southern European countries like Italy, Spain, and Greece, yet relatively few households in these countries own their home through a mortgage. On the other hand, mortgages are very widespread among homeowners in Denmark, the Netherlands, and the UK. The likely causes of this asymmetry between the prevalence of homeownership and expansion of mortgage markets in Europe merit further investigation. In this paper, we focus instead on

\footnotetext{
${ }^{1}$ For a recent cross-country comparison of household wealth holdings in both sides of the Atlantic, see Christelis, Georgarakos and Haliassos (2009).
} 
disparities in households' borrowing attitudes, given that they face mortgage markets with a different degree of expansion.

It is often presumed that if more people in a society get into debt, they become more familiar with the idea of borrowing and subsequently less concerned in servicing a high debt burden. Such a conjecture has often been made in the UK, for example, to justify how, from a common sense of shame about debt in the past, households have recently moved to a debt of more than 1 trillion pounds and to mortgage borrowing that can in some cases exceed house purchasing prices. $^{2}$ In this paper, we find novel empirical evidence that households' perceived vulnerability to debt is crucially affected not only by their own indebtedness, but also by the fact that their own debt burden exceeds that of households in their reference group. Moreover, the influence of relative indebtedness is particularly strong in countries with less expanded mortgage markets lending empirical support to the above conjecture.

We use household-level, internationally comparable panel data from the European Community Household Panel survey (ECHP) which represents a rich source of information on incomes, various demographics, mortgage indebtedness, and subjective well-being. The ECHP asks households explicitly about their financial difficulties due to mortgage repayments and housing costs. We exploit this information to investigate the extent to which mortgage indebtedness induces financial distress across countries with a different expansion of mortgage markets, while the panel nature of the survey allows us to take into account the fact that reported difficulties are to a certain degree subjective.

\footnotetext{
${ }^{2}$ See for example the article "How debt culture took root", by Julian Knight at BBC online news; available at: http://news.bbc.co.uk/2/hi/business/3837419.stm
} 
Recent studies have used the ECHP to examine determinants that increase the likelihood of a household to fall into arrears (Duygan and Grant, 2009) and to associate such incidents with institutional factors, like information sharing arrangements, judicial efficiency, and individual bankruptcy regulation (Jappelli, Pagano, Di Maggio, 2008). Our focus is quite different. We explore the links between mortgage indebtedness and reported distress to gain insights into households' assessment of their debt burden and the associated propensity to assume a debt load that under adverse macroeconomic conditions may prove infeasible to service.

First, we show that a higher mortgage debt to income ratio represents a key determinant of financial distress. However, a given level of indebtedness creates much higher distress in Southern countries, France, and Belgium, where a minority of households have a mortgage outstanding, compared to countries where a sizeable part of the population uses mortgage debt like the UK, the Netherlands, and Denmark. This effect is net of ppp-adjusted income levels, a rich set of socioeconomic characteristics, housing attributes, as well as country-specific constant terms and unobserved household perceptions about indebtedness that are taken into account in our estimations that exploit the panel dimension of the data.

We then probe further into possible explanations behind this asymmetry. We initially draw from the growing research that examines the influence of income on subjective well-being. This literature has identified a key role for the comparison income effect that highlights the importance of interdependence among individual preferences. ${ }^{3}$

\footnotetext{
${ }^{3}$ See for example the studies by Easterlin, 1995, Clark and Oswald, 1996 and Ferrer-i-Carbonell, 2005. A well documented empirical finding of this literature is that individual well-being is affected not only by own income but also
} 
In this paper, we examine the possibility that households' assessment of their own indebtedness is partly made with reference to the debt position of their peer group. Notably, we find new evidence that a non-trivial part of the reported distress is due to the fact that own indebtedness exceeds the median debt burden of reference households. This effect is net of own indebtedness, own income, various demographics and housing attributes, while our estimation takes into account household-specific unobserved heterogeneity and allows for country-specific constant terms.

Reference to the debt load of other households is estimated to have a particularly strong effect on reported distress in countries with less expanded mortgage markets, while it is not quantitatively significant in countries with a high share of mortgage holders. These results imply that households evaluate their own debt burden partly in comparison to the debt load of their peer group and in a way consistent with social stigma considerations. Such considerations seem to induce additional distress among mortgage holders in the less expanded mortgage markets, and they are likely, other things equal, to discourage households from assuming a higher debt burden. On the other hand, as the pool of mortgage holders gets larger, households appear less concerned about their own indebtedness in comparison to that of their reference group and thus relative indebtedness does not represent any more a limiting factor for assuming a higher debt burden.

Finally, we compare differences in distress across countries due to a given debt load with various aggregate indicators of the institutional environment prevailing in each country as well as with cultural differences in household views about indebtedness and in

by comparisons to the income of the reference group. The higher the own income of a given individual is in comparison to the income of other people in society, the higher the welfare of this individual, other things equal. We will review this literature and discuss its links to our study in more detail in Section 3. 
reporting styles. This examination points to the importance of expanded mortgage and credit markets and of the easier access to liquidity that these facilitate in reducing financial distress among households with a high debt burden in the UK, Denmark, and the Netherlands.

Taken together, our findings suggest that more expanded credit markets in general tend towards smoothing consumption over the lifecycle and decreasing the distress households feel from servicing a high debt burden. That is households' assessment of a debt burden and their sense of responsibility with regard to borrowing may tend to diminish and this process can be reinforced by reference to other households in the growing pool of debt holders.

The rest of the paper is organized as follows. Section 2 presents background information on home ownership rates and the expansion of mortgage markets in 12 European countries. Section 3 briefly reviews the related literature, presents the econometric model, and discusses empirical results from the baseline specification. Section 4 extends the analysis of the previous section to examine the role of the relative indebtedness. Section 5 discusses the links with various country-specific institutional indicators. Finally, Section 6 concludes.

\section{Home ownership rates and mortgage markets in Europe}

We utilise survey data from the ECHP, a rich source of information on European households' well being, mortgage indebtedness, demographic characteristics, and housing attributes. Its common design facilitates a direct cross-country comparison that is not affected by data differences due to definitions or measurement. The period from 1994 
(the first year that data from this survey were made available) to 2001 was a period of decreasing interest rates, while more recently households have experienced an increase in interest rates and a boom in housing prices, at least until 2007.

Home ownership and mortgage rates from 2001 (i.e. the most recent ECHP wave) both unconditional and conditional (among home owners), are summarized in Table 1. For each figure, we also report the difference (in percentage points) since 1994. The incidence of home ownership is quite heterogeneous across European countries. Spain, Greece, and Italy show the highest rates with more than $75 \%$ of households owning the house they live in. There are also high home ownership rates in Belgium, the UK, and Portugal. At the other extreme, Austria and Germany display the lowest rates, with less than $50 \%$ of German households classified as owners. Data suggest an expansion in home ownership across Europe in the second half of 1990s, particularly in Denmark.

Home ownership rates in Europe do not correlate with the breadth of mortgage markets. According to the conditional percentage of mortgage holders more than eight out of ten home owners in the Netherlands and Denmark have a mortgage outstanding. Owning a home through a mortgage is also quite common in the UK. On the other hand, in the Southern countries where home ownership is widespread, only a minority of households has a mortgage, with the most pronounced cases being Italy and Greece where $15 \%$ and $10 \%$ of homeowners respectively have a mortgage outstanding. Even in some central countries with quite high home ownership rates, like France and Belgium, mortgage outstanding rates among owners are well below 50\%. Looking at changes since 1994, we observe that Portugal represents the case with the largest expansion in mortgage markets over the period considered, followed by Spain. The picture is quite different for 
Italy and Greece where home ownership has increased at a faster pace compared to mortgage outstanding rates.

In Table 2, we present some macro indicators that show that mortgage markets are significantly expanded in Denmark, the Netherlands, and the UK, while they are much less expanded in Southern countries. In particular, the household debt to GDP ratio is the largest in the three former countries and quite small in Southern ones. Furthermore, as the aggregate indicator of domestic credit market regulation suggests, the first three countries have relatively deregulated private banking systems compared to those in the South.

\section{Which factors contribute to financial distress among mortgage holders?}

\subsection{General Framework}

Existing literature has studied the association between household indebtedness and various socio-economic determinants by mainly focusing on factors that influence household arrears. May and Tudela (2005) find that British households with an unemployed head and with a high loan to value ratio have greater difficulties in meeting scheduled mortgage payments. Del Rio and Young (2005) show that the higher the unsecured debt to income ratio and the mortgage income gearing, the more the problems in servicing debts. Diaz-Serrano (2004) examines, using the ECHP, the determinants of mortgage delinquency across 12 EU countries. He documents a positive association between income volatility and the risk of mortgage delinquency. Duygan and Grant (2009) employ the same data to examine the effects of adverse shocks that households experience (e.g. unemployment) on the likelihood to fall into arrears. They find that adverse events are important, but the extent to which they matter varies across countries 
according to institutional differences in punishment and cost of default. Furthermore, there are studies presenting descriptive evidence on the distribution of debt across households with different characteristics in a given country (see for example Beer, Mooslechner, Schurz, and Wagner, 2006 for Austria; Herrala, 2006 for Finland; Carrascal, 2004 for Spain; Farinha, 2003 for Portugal; and Tudela and Young, 2003 for the UK).

In a related framework, various studies have emphasized the role of social stigma on US households' decision to file for bankruptcy. Fay, Hurst and White (2002) show that such a decision is positively influenced by the financial benefit from filing and by the filing rates in the region of residence that represent an inverse proxy for the level of bankruptcy stigma. Gross and Souleles (2002) using administrative data find that after taking into account changes in risk related and economic factors, the propensity to default has increased over time, which can be attributed to a fall in stigma.

A different strand of literature has utilized survey data with self-reported information on happiness or general well-being to examine associations with individual income (mainly) and other demographics. Most of the studies document a positive, but relatively limited association between income and subjective well-being (see for example, Clark and Oswald, 1994 for the UK; Frey and Stutzer, 2000 for Switzerland; and Ferrer-i-Carbonell and Frijters, 2004 for Germany).

In the above context, a growing literature examines the possibility that individual well-being is affected to a significant extent by comparisons with the income of a reference group. A common empirical finding of these studies is that individual wellbeing is negatively influenced by others' income (for early studies that point to 
preference interdependence and the negative impact of income earned by a reference group on an individual's utility, see Kapteyn, van Praag and Herwaarden, 1978 and Kapteyn and Herwaarden, 1980). Clark and Oswald (1996) find evidence that a worker's job satisfaction is negatively affected by the income earned by other individuals in her reference group. McBride (2001) shows that individuals who believe that they are in a worse financial position relative to their own parents or earn less in comparison to their reference group are less satisfied. Ferrer-i-Carbonell (2005) using German panel data has examined in more detail the importance of comparison income for individual satisfaction. The author finds that the income of the reference group is as important as the own income for an individual's well-being and that individuals tend to be better-off the larger their income is in comparison with the income of their peers.

There is also emerging research that finds peer group effects on household consumption and portfolio decisions. Various studies have argued that individual consumption behavior is determined to some extent by reference to the consumption decisions of other households (see for example, Frank, 1985, Childers and Rao 1992, and Charles, Hurst and Roussanov, 2007). Madrian and Shea (2001) and Duflo and Saez (2002) show that individuals' decisions about their retirement investment plans are influenced by the choices of their work colleagues. Hong, Kubik and Stein (2004) provide evidence that sociability fosters stock market participation possibly because information acquired through word-of-mouth lowers information costs. Consistent with a peer-effects story the authors estimate stronger effects of sociability in US states with widespread stock market participation. 
Our analysis is partly motivated by the literature examining the effect of income on subjective well-being and the role of the comparison income effect. We first study the extent to which mortgage indebtedness influences reported financial distress. Then, we link reported distress with every household's debt burden in comparison to that assumed by its reference group. With reference to studies examining the determinants of household arrears, our focus tends to be broader. The incidence of arrears is typically relevant for a relatively small share of households. Households under heavy distress due to a high exposure to debt do not only run the risk of falling into arrears, but they are also more likely to make considerable adjustments to their consumption, portfolio, and borrowing behaviour. In addition, choosing to service a debt burden that can later represent a significant source of distress can be indicative of limited financial sophistication and poor financial planning. Thus, understanding how households assess their indebtedness and what shapes their attitudes towards borrowing can offer useful insights to economists, practitioners, and policy makers.

We base our empirical investigation on information drawn from the following specialised question that is asked to mortgage holders: "Please think of your total housing cost including mortgage repayments, repairs, municipal or property tax, heating, water and sewerage charges. To what extent are housing costs a financial burden to you?". Each household can choose among the following answers: "a heavy burden", "somewhat a burden", and "not a problem". The question is designed to capture households' perceptions about the influence of mortgage repayments and housing costs in particular, on their financial situation more generally. Given that this question explicitly links housing costs with financial difficulties and that information on various housing 
attributes capturing housing related expenditures is available in the survey, we are in a position to investigate more closely the effect of mortgage indebtedness on financial distress.

Table 3 summarizes responses to the question of interest across countries. Higher levels of distress among mortgage holders are reported in Italy, Spain, Greece, and Portugal, while the lowest levels are found in the Netherlands, the UK, Denmark, and Austria. We also report the mean, median, lower and upper quartiles, and standard deviation of the mortgage debt to income ratio that - with the exemptions of Austria and Greece - are quite similar across countries. The average median ratio implies that a typical European mortgage holder pays $18 \%$ of her income in servicing her mortgage debt. These summary statistics do not suggest an obvious correlation pattern between the mortgage debt to income ratio and household financial distress.

\subsection{Model specification}

Our model description follows that of Ferrer-i-Carbonell (2005) who has used panel data to study the effects of own and comparison income on self-reported wellbeing. Household distress due to housing costs is not directly observable. What is observed instead is a household's assessment of whether such costs represent a heavy financial burden (if the latent distress exceeds some critical threshold) or not (if the latent distress is below this threshold). We can express the latent distress due to housing costs $\left(d h c^{*}\right)$, using the following specification:

$$
d h c_{i t}^{*}=c+X_{i t}^{\prime} \beta+\gamma_{1} D S R_{i t}+\gamma_{2} D S R_{i t}^{2}+\delta \log \left(Y_{i t}\right)+u_{i t}
$$


where $i$ is a household specific index, $t$ represents time, $X_{i t}$ is a matrix of observed variables made up of various household demographics and housing attributes and $u_{i t}$ is an error term. In addition, we also allow for a non-linear influence of after tax income $(Y)$ and of the mortgage debt to income ratio $(D S R)$ that a household has to service. ${ }^{4}$ Thus, the latter represents an indicator of indebtedness at given levels of income.

Given the panel nature of the survey, we can adjust specification (1) to take into account time fixed effects and individual-specific random effects. With reference to the former, we include year dummies that allow for time changes that affect all households. In our set-up the time dummies are likely to capture yearly changes in housing prices, in housing costs, and/ or in mortgage interest rates. The individual random effects represent unobserved personal traits and attitudes that are time-invariant unit-specific, like household optimism or perceptions about indebtedness. Thus, provided that answers to the question about distress are to some extent subjective, we take into account the possibility that for given $X$ 's, income, and degree of indebtedness, those households with a positive outlook on life or lower aversion to debt will tend to report lower distress compared to their more pessimistic or debt-averse counterparts. The error term in (1) can be written as a function of two components, a household-specific component that does not vary with time and a remainder component which is assumed to be uncorrelated over time:

$$
u_{i t}=\alpha_{i}+\varepsilon_{i t}
$$

\footnotetext{
${ }^{4}$ DSR is calculated as the ratio of mortgage debt repayment (i.e. last month's mortgage instalment multiplied by 12) over the yearly net household income. Thus, the use of a logarithmic transformation in order to capture the non-linear effects of DSR (instead of a second order polynomial) would have cancelled out the logarithm of net income term. In addition, a DSR second order polynomial found preferable against alternative functional forms in terms of model's goodness of fit according to both the Akaike and Schwarz information criteria.
} 
Both error components are assumed to be independently distributed from other covariates in the model. In our set up, this is a rather strong assumption given that optimism and perceptions about debt are likely to correlate with income and the degree of indebtedness. To take into account this possibility we allow individual household effects in our panel specification to be determined by time averages of (a subset of) the observable variables (see Mundlak, 1978):

$$
a_{i}=\bar{Z}_{i}^{\prime} \pi+\omega_{i}
$$

where $\omega_{i}$ is iid. In $Z$ we include variables such as the mortgage debt to income ratio (and its square) and net income. Then, by incorporating time fixed effects and individual random effects, specification (1) can be rewritten as:

$$
d h c_{i t}^{*}=c+\tau T+X_{i t}^{\prime} \beta+\gamma_{1} D S R_{i t}+\gamma_{2} D S R_{i t}^{2}+\delta \log \left(Y_{i t}\right)+\bar{Z}_{i}^{\prime} \pi+\omega_{i}+\varepsilon_{i t}
$$

where $\omega_{i} \sim N\left(0, \sigma_{\omega}\right)$ and $\varepsilon_{i t} \sim N(0,1)$ that is also assumed to be uncorrelated over time. Under the above assumptions, we estimate the random effects probit which incorporates the Mundlak adjustment producing consistent estimates. We estimate specification (4) separately for each country over the full unbalanced panel of households with a mortgage outstanding.

With reference to the household demographics we take into account the age of the household head and his/her employment status (self employed, retired, other inactive/unemployed, with employees forming the omitted category). We control for gender and marital status by group dummies that distinguish among single males, couples living together and single females (that form the reference group). We also add a dummy representing children aged less than 16 years in the household. Younger children act both 
as a strain on current resources and may be associated with committed future expenditures, thus increasing the financial demands on a household. In addition, we take into account the educational attainment of the household head (college graduate, high school graduate, with those with less than high school education being in the reference group) that can approximate (future) income prospects. ${ }^{5}$ Education may also account for households' ability to identify the best terms and conditions when they borrow and to remortgage on time when they face favourable conditions. Moreover, we account for the likely distress that bad health may generate. In particular, we control for the worse reported health status within a household, given that families may be affected in their borrowing decisions as well as in the financial difficulties they report by the adverse health condition of any of their household members.

We also distinguish immigrant households, given that they may face additional economic difficulties, e.g. through greater job uncertainty. Moreover, we include two indicators of sociability, showing whether the household head participates in a political or social/sports club or organization and whether he often meets friends. More sociable households may be more likely to get financial support from family and friends, like money transfers helping younger households to meet their mortgage payments. The role of such informal credit channels can be particularly important in countries with less expanded credit markets.

The data offer enough information to allow us to account for housing attributes that are related to housing costs. We control for size of the home by including a

\footnotetext{
${ }^{5}$ Lifecycle models predict that households facing upward future income profiles (such as the more educated) should optimally borrow early on in life.
} 
categorical variable that represents the number of rooms. We also take into account the number of years that a household lives in its current accommodation which proxies for the time elapsed since a mortgage was taken out. This is also likely to capture any relevant repair and maintenance costs that are typically higher for older accommodation. Furthermore, we take into consideration differences due to the type of accommodation, using a flexible specification with single dummies that represent the following types: detached single-family house, semi-detached or terraced single-family house, apartment or flat in a building with less than 10 dwellings, apartment or flat in a building with 10 or more dwellings and other accommodation (that forms the base category).

Finally, we have incorporated a complete set of dummy variables representing the regions in which a household lives in each country. This is potentially important given that housing prices and housing costs can vary across regions within a country and a specification that accounts for differences due to regional-specific factors facilitates an even closer investigation of the effects of mortgage indebtedness on households' financial difficulties. In what follows we present results from models that are estimated independently for each country, which is the most flexible specification that one can employ. ${ }^{6}$ As we discuss in Section 5, constant terms in these models pick up a significant part of differences in various country-wide factors that are likely to affect country heterogeneity in reported distress.

\footnotetext{
${ }^{6}$ Estimating the model independently for each country is equivalent to estimating the same model for the pooled sample of countries when the latter includes, apart from the set of covariates, country dummies as well as a full set of interaction terms of each covariate with country dummies.
} 


\subsection{Discussion of Results}

Coefficients from discrete choice models are not directly interpretable, thus we calculate and report average - across mortgage holders in each country - marginal effects on the probability of declaring housing costs as a heavy burden along with their significance. Marginal effects for selected covariates are presented in Table 4 for every country separately.

In all countries, health problems significantly increase the likelihood of reporting housing costs as a heavy burden. The estimated effects are particularly strong in Southern countries (Italy, Spain, Portugal, and Greece) and in Finland. Households with health problems typically face higher job and income uncertainty as well as increased medical expenses and these factors contribute to higher distress. Children are often thought to act as an additional strain on resources and this is likely to be reflected in the positive significant estimates we derive for most of the countries. These results imply that households may have not fully taken into account the costs associated with children before deciding to borrow and thus children show up as an additional source of distress when servicing mortgage debt.

We find that education significantly reduces financial distress in Southern countries and in Austria. Better-educated households are likely to be more capable of understanding mortgage terms and conditions and to shop around for the best alternatives before borrowing. In a recent study Lussardi and Tufano (2008) present evidence that households with lower financial literacy tend to judge their debt as excessive. Such differences in financial sophistication and in borrowing practices are likely to reflect upon financial distress when servicing the debt and seem to be more relevant in countries 
with less expanded mortgage markets. Higher education may also account for better career prospects and thus households that enjoy job security and face upward-sloping future income profiles appear - in the aforementioned countries - less distressed relative to their less educated counterparts with a mortgage outstanding.

As regards the role of labor status, the self employed, despite their exposure to entrepreneurial risk, appear less concerned about financial difficulties - compared to employees - in Southern countries, France, Belgium, Germany, and Finland. This result may be due to some broader wealth effects. It may also reflect the fact that entrepreneurs are more familiar with the idea of borrowing relative to employees who have a mortgage outstanding and this difference becomes more evident in the less expanded markets. On the other hand, in almost all countries, being unemployed increases the probability of declaring distress. The effect is consistent with liquidity constraints and the poorer job prospects that the unemployed usually face.

We find that controlling for income, labor status, and rate of indebtedness, immigrant households are more distressed only in France. On the other hand, they are less distressed in Finland, Spain and Portugal, while the effects in the other countries are insignificant. ${ }^{7}$ These results suggest that immigrants who have received approval for a mortgage form a well established group with good and stable longer run job prospects in the host country and similar or even less financial difficulties compared to natives. As regards the two sociability indicators they do not suggest any significant influence with

\footnotetext{
${ }^{7}$ Information about immigrant status is not available in the United Kingdom and Germany, while in the Netherlands being an immigrant predicts financial distress perfectly.
} 
the only exception being interactions with friends, which imply higher distress in Finland and in Greece.

We also find that for most countries in the sample income levels matter and that those with higher disposable incomes, controlling for the degree of indebtedness and various other factors, are less financially distressed. ${ }^{8}$ Households with higher net income levels, even if they have to sustain a high mortgage debt to income ratio, have more money available to spend and meet the basic standards of living. In addition, they are likely to enjoy easier access to other forms of credit that can boost their liquidity. ${ }^{9}$

Estimates on housing attributes do not show a uniform picture and this is likely to arise from differences in housing conditions across European countries. For example, the number of years lived in a home contributes positively to reported distress in Finland, France, and Spain. The size of the home is associated with higher distress in Denmark and lower distress in the UK, Germany, Spain, Portugal, and Greece.

Given that we control for household income as a separate regressor, we measure the effect of the DSR on reported distress due to housing costs net of the level of (pppadjusted) disposable income. We present the relevant effect of our key variable of interest in two ways. First, in Table 4 we show the average influence on reported distress from an assumed 10 percentage points (pp) increase in the mortgage debt to income ratio. Second, we compute and plot the predicted probabilities of distress for each country over a wide spectrum of mortgage debt to income ratios (from .01 to 1) based on the regression

\footnotetext{
${ }^{8}$ We report average marginal effects that refer to a change in the probability of declaring housing costs being a heavy burden as a result of an assumed 1,000 (ppp-adjusted) monetary units increase in income that take into account apart from the increase in income levels the associated decrease in mortgage debt to income ratio.

${ }^{9}$ We also experiment with specifications that include a dummy for whether households have any consumer debt and the results are similar to those we present.
} 
models we have estimated. The graphs are illustrated in Figure 1. In each graph, we superimpose a vertical line indicating a ratio of 0.3 . This is a 'benchmark' cut off point that is frequently used by financial practitioners to classify an individual as a risky borrower in the sense that it is likely to face severe difficulties in servicing her debt. ${ }^{10}$

In all countries, an assumed $10 \mathrm{pp}$ increase in the mortgage debt to income ratio implies significantly higher probabilities of reporting financial difficulties. The quantitatively strongest effects are derived in Belgium, Spain, Portugal, and Greece, while the smallest ones in the UK and the Netherlands. By looking at Figure 1, it becomes apparent that the probability of reporting distress as a function of mortgage debt to income ratio, after controlling for various factors, are very different across countries. On the one hand, mainly in Italy, Spain, Portugal, and Greece, but also in Belgium and France, mortgage indebtedness represents a major source of distress. On the other hand, much smaller effects are derived for the UK, the Netherlands, and Denmark, while intermediate effects are implied for Germany, Finland, and Austria. In other words, a typical mortgage holder in Italy or Spain, who spends for example half of her income in servicing her debt, reports much higher distress than her counterpart in the UK or the Netherlands. This effect is estimated net of (ppp-adjusted) after tax incomes levels, various demographics, regional variation, housing attributes, and individual-specific unobserved heterogeneity. Our estimation also allows for country-specific constant terms that capture a significant part of country fixed effects.

In a later section we probe further into the aforementioned asymmetry by examining the potential links with the institutional environment prevailing in each

\footnotetext{
${ }^{10}$ See for example DeVaney and Lytton (1995).
} 
country. Before doing so, we extend the analysis of the current section to examine the possibility that households' assessment about their own debt burden is made to some extent with reference to the debt load of households in their comparison group. As it was discussed this investigation is partly motivated from the well documented empirical finding that self-reported well-being is negatively influenced by the income of the reference group.

\section{The role of relative mortgage indebtedness}

In the previous section we showed that the rate of indebtedness represents a significant source of financial distress for households and that the estimated effects were particularly strong in countries with less expanded mortgage markets. In this section we examine the possibility that declared distress is also affected by reference to the debt burden of other households in a given country. This would mean that households do not assess their own indebtedness based only on their own preferences, resources, and configuration of characteristics.

Following existing literature on subjective well-being and happiness we combine criteria like age and education to define a reference group within each country (see e.g. Clark and Oswald, 1996 and Ferrer-i-Carbonell, 2005). More specifically, within each country we consider five-year bands over the age range of our sample (20 to 75$)$, which are combined with more than high school and less than high school educational attainment to produce twenty two age-education cells. Then, we calculate for each ageeducation cell the median mortgage debt to income ratio among mortgage holders. In our 'baseline' model (1), which takes into account own net income, own debt burden, various 
demographics and housing attributes, we add a dummy indicator that is equal to one if a household has a mortgage debt to income ratio in excess of the median corresponding ratio of its reference group and zero otherwise.

Marginal effects and associated standard errors with respect to own and relative indebtedness are presented in Table 5. Results suggest that a mortgage debt to income ratio in excess of the corresponding median burden of reference households represents an independent source of distress in most of the countries. That is, relative indebtedness matters for distress and has an effect over and above the influence of own income and own mortgage debt to income ratio. The implied effects are consistent with social stigma considerations and are particularly strong in Italy, Spain, Portugal, Greece, and Belgium. For example, a mortgage holder in Italy with a given income and debt burden to service has a $7 \mathrm{pp}$ higher probability to declare financial difficulties due to the fact that her own indebtedness exceeds that of her reference group.

On the other hand, the corresponding effects in countries with expanded mortgage markets are either quantitatively unimportant (UK, Netherlands) or statistically insignificant (Denmark). This suggests that over-indebtedness relative to the debt burden of the reference group does not represent a considerable source of distress in countries where a significant segment of the population has a mortgage outstanding. The results we present above have been proved robust to alternative definitions of the reference group as well as to different functional forms of the baseline model. Results from these robustness exercises are presented in Appendix A.

All in all, our findings point to an independent role of relative over-indebtedness on financial distress that is stronger in countries where a smaller segment of the 
population has a mortgage outstanding. Such a role is consistent with social stigma considerations of those with a debt load in excess of that of reference households in countries with less expanded markets. Yet, the distress that reference to the debt burden of other households generates tends to be eliminated in countries where a sizeable portion of the population uses mortgage debt. That is, households' assessment of the debt burden diminishes as the share of mortgage holders increases and subsequently households in these countries are - other things equal - less concerned about servicing a given debt burden.

Still, results from this section suggest that a given level of own indebtedness creates higher distress in less expanded mortgage markets, even when the influence of relative indebtedness, ppp-adjusted income levels, and various household characteristics, as well as country-specific constant terms have been taken into account. In what follows, we attempt to link this asymmetry, identified from survey data, with various aggregate indicators of the institutional and social environment in each country.

\section{Cross country differences in institutions and household beliefs about debt}

It should be noted that a significant part of country-wide differences in reported distress are picked up by the country-specific constant terms in our models. Such differences can range from country differences in the legal, institutional, and banking environment to differences in culture and in reporting style. Recent studies have attempted to associate international disparities in household debt repayment behaviour with particular aspects of the institutional environment prevailing in each country. Such associations are modelled by using relevant country-invariant indicators as additional 
regressors to household-specific characteristics. ${ }^{11}$ Given that our study focuses on disparities in the effect of household-specific indebtedness on reported distress, we choose to account for any country wide differences at large by allowing for countryspecific constant terms. Yet, it still may be the case that some remaining country-wide discrepancies partly show up in differences in the estimated marginal effects of the household-level variable of interest. Hence, in what follows we present various aggregate indicators that are likely to influence reported distress and we discuss their possible links with the pattern we identify from the survey data (i.e. the asymmetric effect that a given debt burden implies for reported distress across different groups of countries).

\subsection{The efficiency of contract enforcement}

We first examine the possibility that households report higher levels of distress in countries with an institutional environment that is more efficient in the collection of overdue debt, making default an even tougher option for the heavily indebted. Following Djankov, McLiesh and Shleifer (2007) we look at three indicators that are suggestive of the efficiency of contract enforcement across countries: the number of procedures from the moment the plaintiff files a claim in court until the moment of payment, the average number of days required to resolve a dispute, and court and attorney fees expressed as a percentage of the debt value. The above indicators are summarized in Table 6 .

\footnotetext{
${ }^{11}$ See for example Duygan and Grant (2009). They use a country invariant indicator of the number of days required to complete the judicial process as a proxy of country differences in the efficiency of the legal system in collecting overdue debts in order to examine the influence on household arrears. In these applications, given the structure of the data (a high number of households and relatively few countries), there is a limited number of country-invariant indicators that one can take into account, since they will be mutually highly collinear. Obviously, one can not use in addition country dummies to account for any remaining country differences, given that these dummies will introduce perfect collinearity. Furthermore, nothing guarantees that estimated effects on these (few) indicators will not pick up various other country differences which can not be taken into account explicitly.
} 
These indicators suggest that punishment costs are not much smaller in countries with expanded mortgage markets, where households are found to be less distressed when they service a high debt burden. On the other hand, in countries like Italy, where households are more distressed for each given rate of indebtedness, it is more costly for lenders to collect any overdue debts. Overall, higher efficiency of the institutional environment as regards contract enforcement does not seem to relate to household propensity to report more financial difficulties in less expanded markets.

\subsection{Changes in housing prices}

Another hypothesis to consider is that households report less distress for a given debt to mortgage ratio in countries that have witnessed a significant appreciation in house prices, effectively reducing the debt burden relative to household wealth. ${ }^{12}$ The first block (I) of Table 7 presents real and nominal house price changes, both over the longer term and over the period captured by the ECHP data, which indeed show rapidly increasing house prices for the UK, Denmark, and the Netherlands, but also for Spain and Greece. Thus, an appreciation in house prices alone does not seem sufficient to explain the pattern of distress that we identified in the data.

\subsection{The role of credit institutions}

Households may also report less distress for a given mortgage debt load if they benefit from the greater availability of credit allowing them easier access to liquidity and more options to refinance. A second block (II) of indicators in Table 7 shows support for the notion that households experience relatively less distress in countries with more

\footnotetext{
${ }^{12}$ In principle the time and regional dummies in our model should have adequately captured such effects.
} 
expanded mortgage and credit markets. For example, households in the UK, Denmark, and the Netherlands face a greater variety of financial products (specialised loans) and a higher supply of loans via the securitisation of mortgages, and are able to take out a larger mortgage relative to the value of a property purchased.

A final hypothesis, which seems to be strongly backed by the available crosscountry indices, is that households experience less stress where mortgage repayments are more predictable and facilitate household financial planning. The third block (III) of indicators in Table 7 identifies Denmark and the Netherlands as countries with a high proportion of loans with long interest rate fixation periods. A different way of looking at this is to consider the volatility and average levels of interest rates. For example, if interest rates are volatile, borrowing households will be less likely to commit to floatingrate mortgages. We present statistics on short and longer-term interest rate volatility in Table 8. The figures suggest indeed that the UK, Denmark, and the Netherlands have experienced much lower volatility and average interest rate levels compared to the other European countries.

\subsection{National differences in household views about debt and in response style}

As a final hypothesis, we examine the possibility that our results reflect countrywide differences in household views regarding borrowing and/ or response style. It should be noted that our estimation has taken into account the fact that unobserved individual traits or perceptions about debt can affect reported distress in a given country. Yet, one may argue that the pattern we identify in the survey data is mainly driven by cultural disparities regarding borrowing or by cross-country differences in response styles and that such differences have not been adequately captured by the country-specific 
constant terms. For example, it may be the case that a typical Italian household finds borrowing dangerous or unethical compared to an average UK household and this could be the reason that a mortgage holder in Italy reports - on average - higher distress for a given debt burden compared to her British counterpart. Another possibility is that a typical Italian household systematically overstates financial difficulties in comparison to a UK counterpart.

National differences in perceptions about borrowing may be partly shaped by a country's history, traditions and norms, and may be partly the outcome of interactions with the prevailing institutional environment. In any case, if households find borrowing dangerous or have ethical barriers to buy on credit in countries with less expanded mortgage markets, then such cultural differences are likely to partly reflect upon our findings. ${ }^{13}$ While such national differences in norms are not easy to quantify, in what follows we take a small step towards this direction.

We employ survey data from Eurobarometer that is a survey frequently conducted across EU countries to measure Europeans views on various issues. We present statistics from Eurobarometer 56.0, which was conducted at the end of 2001 (i.e. the last year covered by the ECHP sample). Respondents are asked to indicate whether they agree or disagree with the following statement:

\section{"Buying on credit is more useful than dangerous"}

The shares of those who agree with this statement for the population as a whole and for mortgage holders in particular for each country are presented in Table 9. The

\footnotetext{
${ }^{13}$ It should be noted that within-country cultural differences, if any, have been absorbed by the regional dummies in our models.
} 
reported statistics do not suggest a clear pattern that can be linked to the expansion of credit markets and to the pattern of the findings of the previous section. If anything, the highest share of those who find in general buying on credit more useful than dangerous is recorded in three of the countries with the less expanded mortgage markets (Spain, Italy, and Portugal).

National differences in the way households tend to report subjective outcomes, like self-reported health status, have recently attracted research attention. ${ }^{14}$ One way to shed more light on this issue is to look at correlations between reported distress and some objective outcomes that are indicative of a household's financial situation. In figure 2 we look at cross-country correlations between the share of mortgage holders reporting distress and their ability to meet scheduled mortgage and other consumer loan payments. In addition, we examine correlations with the average number of durables in each country. ${ }^{15}$ If households that report severe difficulties face actual problems with their finances, they should tend to fall more frequently into debt arrears and possess a smaller number of home durables.

The descriptive evidence from these correlations appears consistent with this prior: countries with a higher share of mortgage holders who report distress tend to rank higher as regards the incidence of mortgage or other loan arrears and lower as regards the average number of home durables. These associations provide us with further confidence

\footnotetext{
${ }^{14}$ In order to take into account cross-country differences in response scales regarding subjective questions, recent surveys ask from households to assess the same hypothetical scenario (vignettes). Based on these responses one can identify country-specific threshold parameters (see King et al., 2004). Information on vignettes is not available in the ECHP.

${ }^{15}$ Households are asked whether they were unable to pay schedule mortgage payments / hire purchase instalments or other loan repayments during the past 12 months preceding the interview. With reference to home durables we consider the number of items owned from the following list: colour television, video recorder, microwave, dishwasher, telephone, and home computer.
} 
that cross-country differences in reporting styles is not the driving force for the pattern we identify in the data.

In sum, examination of various country-wide indicators in this section suggests the importance of the expanded mortgage and credit markets and of the easier access to liquidity that these facilitate in reducing financial distress among households with a high debt burden particularly in the UK, Denmark, and the Netherlands.

\section{Conclusions}

This paper has studied households' borrowing behaviour by exploring the links between mortgage indebtedness and financial distress across 12 European countries at different stages of mortgage market expansion. Our analysis yields insights into households' assessment of debt and their propensity to assume a debt burden that under adverse macroeconomic conditions might prove infeasible to service.

We find that less education, health problems, and unemployment generate financial distress in most countries. We also find that a higher mortgage debt to income ratio is a key determinant of financial distress. However, the debt load that a typical household has to service creates much higher distress in Southern countries, France, and Belgium, where relatively few have a mortgage outstanding compared to countries with expanded mortgage markets like the UK, the Netherlands, and Denmark. This effect is estimated net of ppp-adjusted income levels, a rich set of socioeconomic characteristics, housing attributes, and country-specific constant terms, while the panel nature of the data allows us to take into account unobserved household-specific traits that influence reported distress. 
Further investigation suggests that incurring a debt burden above the median debt load of reference households represents an independent source of distress and this effect is net of own indebtedness, own income, various socio-economic characteristics, and housing attributes. This finding is consistent with social stigma considerations. Estimated effects on relative indebtedness are particularly strong in countries with less expanded mortgage markets, while they lose significance in countries with widespread mortgage debt. Our results imply that in the former case social stigma considerations are stronger and can discourage households from borrowing additional amounts. On the other hand, in countries with expanded mortgage markets households appear less worried about their relative debt position and therefore less concerned in assuming a higher debt burden.

The comparison of our findings with various aggregate indicators suggests that the state of mortgage and credit market expansion also plays a role in explaining why households with a given debt burden to service are relatively less distressed in the UK, Denmark, and the Netherlands. An appreciation in house prices alone is not sufficient to explain cross-country differences in reported distress. Rather, households are found to experience less stress for a given amount of indebtedness in counties where average interest rate levels and volatility are lower, and thus where mortgage repayments are more predictable and facilitate household financial planning. Furthermore, the aggregate indicators support the notion that households should experience relatively less distress in countries with more expanded mortgage and credit markets where they can choose from a variety of financial products and are able to take out a larger mortgage relative to the value of a property purchased. On the other hand, the cross-country differences in reported distress do not seem to relate with national differences in the efficiency of 
institutions to collect overdue debts or cultural differences regarding the usefulness of credit or cross-country differences in reporting style.

Given that the mortgage markets are relatively less expanded in many European countries, there is a significant potential for expansion. However, at the same time, there is an obvious need to ensure that this development supports "informed" borrowing. Identifying the rules to guide future policy is not immediately obvious. Our results suggest that as the pool of mortgage holders expands, households are less concerned about relative indebtedness and become accustomed to the idea of borrowing higher amounts. More expanded markets in general contribute to consumption smoothing and tend towards decreasing the financial distress households feel from holding debt. That is households' assessment of the debt burden and the sense of responsibility about borrowing may diminish and this process can be reinforced by reference to other households in the same boat.

This kind of attitude towards indebtedness that we have identified could be of key interest to policy makers. Assuming additional borrowing may not be a problem during periods of rising housing prices, low interest rates, and low unemployment. However, it may create several problems during economic turbulence and in the absence of an obvious "corrective" mechanism on which to rely. Policy makers need to take into account that expanded markets not only offer easier access to credit but are also likely to induce additional borrowing by mitigating the importance of the relative indebtedness. That is credit market expansion should be accompanied by financial education and more responsible lending from the side of financial institutions. 


\section{References}

Beer, C., Mooslechner, P., Schurz, M., Wagner, K. (2006). 'Austrian households' financial wealth: an analysis based on microeconomic data', Monetary Policy and the Economy Q2/06, OeNB, pp. 94-110.

Carrascal, C.M. (2004). 'La carga financiera de las familias espanolas: a primer analysis desagregado', Banco de Espana Boletin Economico, pp. 67-78.

Charles, K.K., Hurst, E., Roussanov, N.L. (2007). 'Conspicuous consumption and race', NBER Working Paper No. W13392.

Childers, T.L., Rao, A.R. (1992). 'The influence of familial and peer-based reference groups on consumer decisions', Journal of Consumer Research, vol. 19 (2), pp. 198-211.

Christelis, D., Georgarakos, D., Haliassos, M. (2008). 'Economic integration and mature portfolios', Center for Financial Studies, WP 2008/05.

Clark, A.E., Oswald, A.J. (1994). 'Unhappiness and unemployment', The Economic Journal, vol. 104 (424), pp. 648-659.

Clark, A.E., Oswald, A.J. (1996). 'Satisfaction and comparison income', Journal of Public Economics, vol. 61, pp. 359-381.

DeVaney, S.A., Lytton, R. H. (1995). 'Household insolvency: A review of household debt repayment, delinquency and bankruptcy', Financial Services Review, vol.4(2), pp. 137-56.

Duflo, E., Saez E. (2002). 'Participation and investment decisions in a retirement plan: the influence of colleagues' choices', Journal of Public Economics, vol. 85(1), pp. 121-148.

Duygan, B., Grant, C. (2009). 'Household debt repayment behaviour: what role do institutions play?', Economic Policy, vol. 24(57), pp. 107-140.

Djankov, S., McLiesh, C., Shleifer, A. (2007). 'Private credit in 129 countries', Journal of Financial Economics, vol. 84(2), pp. 299-329.

Del Rio, A., Young, G. (2005). 'The impact of unsecured debt on financial distress among British households', Documentos de Trabajo, No. 0512, Banco de Espana.

Diaz-Serrano, L. (2004). 'Income volatility and residential mortgage deliquency: evidence from 12 EU countries', IZA Discussion Paper Series, No. 1396.

Easterlin, R.A. (1995). 'Will raising the incomes of all increase the happiness of all? Journal of Economic Behavior and Organization, vol. 27(1), pp. 35-47. 
Farinha, L. (2003). 'The effect of demographic and socioeconomic factors on households' indebtedness', Economic Bulletin, Banco de Portugal 9(2), pp. 33-44.

Fay, S. A., Hurst, E., White, M. J. (2002). 'The consumer bankruptcy decision', American Economic Review, vol. 92(3), pp. 706-718.

Ferrer-i-Carbonell, A. (2005). 'Income and well-being: an empirical analysis of the comparison income effect', Journal of Public Economics, vol. 89, pp. 997-1019.

Ferrer-i-Carbonell, A., Frijters, P. (2004). 'The effect of methodology on the determinants of happiness', The Economic Journal, vol. 114, pp. 641-659.

Frank, R.H. (1985). 'The demand for unobservable and other non-positional goods', American Economic Review, vol. 75, pp. 101-116.

Frey, B.S., Stutzer, A. (2000). 'Happiness, economy and institutions', Economic Journal vol. 110, pp. 918-938.

Gross, D. B., Souleles, N. (2002). 'An empirical analysis of personal bankruptcy and delinquency', Review of Financial Studies, vol. 15(1), pp. 319-347.

Herrala, R. (2006). 'Household indebtedness', Bank of Finland Bulletin 1/2006, pp. 9199.

Hong, H., Kubik, J.D., Stein, J.C. (2004). 'Social interaction and stock market participation', Journal of Finance, vol. 59(1), pp. 137-163.

Jappelli, T., Pagano, M., Di Maggio, M. (2008). 'Households' indebtedness and financial fragility', CSEF Working Papers No. 208, University of Naples, Italy.

Kapteyn, A., van Herwaarden, F.G. (1980). 'Independent welfare functions and optimal income distribution', Journal of Public Economics, vol. 14, pp. 375-397.

Kapteyn, A., van Praag, B.M.S., van Herwaarden, F.G. (1978). 'Individual welfare functions and social preference spaces', Economics Letters, vol. 1, pp. 173-177.

King, G. A., Murray, C. J. L., Salomon, J.A., and Tandon, A. (2004). 'Enhancing the Validity and Cross-Cultural Comparability of Measurement in Survey Research', American Political Science Review, vol. 98 (1), pp. 191-207.

Lussardi, A. and Tufano, P. (2008). 'Debt literacy, financial experiences, and overindebtedness', NBER Working Paper No. w14808.

Madrian, B.C., Shea, D.F. (2001). 'The power of suggestion: inertia in 401(k) participation and savings behavior', Quarterly Journal of Economics, vol. 116(4), pp. 1149-1187. 
May, O., Tudela, M. (2005). 'When is mortgage indebtedness a financial burden to British households? A dynamic Probit approach', Bank of England Working Paper Series No. 277.

McBride, M. (2001). 'Relative-income effects on subjective well-being in the crosssection', Journal of Economic Behavior and Organization, vol. 45, pp. 251-278.

Mundlak, Y. (1978). 'On the pooling of time series and cross section data', Econometrica, vol. 46, pp. 69-85.

Tudela, M., Young, G. (2003). 'The distribution of unsecured debt in the United Kingdom: survey evidence', Bank of England Quarterly Bulletin, pp. 417-427. 
Table 1: Home ownership and mortgage outstanding rates (in percentages)

\begin{tabular}{|c|c|c|c|c|c|c|}
\hline & \multicolumn{2}{|c|}{ Home ownership rates } & \multicolumn{2}{|c|}{$\begin{array}{l}\text { Mortgage outstanding } \\
\text { rates (Unconditional) }\end{array}$} & \multicolumn{2}{|c|}{$\begin{array}{c}\text { Mortgage outstanding rates } \\
\text { (Conditional on home } \\
\text { ownership) }\end{array}$} \\
\hline & 2001 & $\begin{array}{r}\text { Diff (p.p.) } \\
\text { since 1994 }\end{array}$ & 2001 & $\begin{array}{l}\text { Diff (p.p.) } \\
\text { since 1994 }\end{array}$ & 2001 & $\begin{array}{c}\text { Diff (p.p.) } \\
\text { since 1994 }\end{array}$ \\
\hline FI & 69 & $5^{\mathrm{a}}$ & 27 & $0^{\mathrm{a}}$ & 39 & $-3^{a}$ \\
\hline UK & 72 & 5 & 41 & 0 & 57 & -4 \\
\hline DK & 67 & 13 & 56 & 10 & 83 & -3 \\
\hline $\mathrm{DE}$ & 43 & 5 & 20 & 1 & 47 & -3 \\
\hline NL & 54 & 7 & 47 & 9 & 88 & 5 \\
\hline $\mathrm{BE}$ & 74 & 7 & 33 & 3 & 44 & 0 \\
\hline FR & 63 & 8 & 26 & 1 & 42 & -5 \\
\hline $\mathrm{AT}$ & 55 & $6^{\mathrm{a}}$ & 22 & $3^{a}$ & 40 & $2^{a}$ \\
\hline IT & 76 & 6 & 11 & -2 & 15 & -4 \\
\hline ES & 85 & 6 & 23 & 6 & 27 & 6 \\
\hline PT & 67 & 6 & 20 & 8 & 29 & 10 \\
\hline GR & 85 & 8 & 8 & 0 & 10 & -1 \\
\hline All & 67 & 5 & 27 & 3 & 40 & 2 \\
\hline
\end{tabular}

Note: Source: weighted statistics from ECHP. ${ }^{\mathrm{a}}$ Differences for FI and AT are calculated since 1996 and 1995, respectively (i.e. the first years that data are available for these countries). 
Table 2: Selected macroeconomic indicators of credit market expansion

\begin{tabular}{|c|cc|}
\hline & $\begin{array}{c}\text { Aggregate indicator of } \\
\text { domestic credit market } \\
\text { regulation (1) }\end{array}$ & $\begin{array}{c}\text { Debt to GDP } \\
\text { ratio \% 2001 (2) }\end{array}$ \\
\hline UK & 9.2 & 60 \\
DK & 9.4 & 67 \\
NL & 9.1 & 74 \\
DE & 7.7 & 47 \\
FR & 8.2 & 22 \\
FI & 9.1 & 21 \\
AT & 8.4 & 30 \\
BE & 8.4 & 28 \\
IT & 6.8 & 10 \\
ES & 8.5 & 32 \\
PT & 8.0 & 47 \\
GR & 7.2 & 12 \\
\hline
\end{tabular}

Note: (1) Source: Economic Freedom of the World 2007. Data is for 2001. Score between 0 and 10. Countries that use a private banking system to allocate credit to private parties and refrain from controlling interest rates receive a higher rating. Indicator captures: i Ownership of banks: Percentage of deposits held in privately owned banks, ii Competition: Domestic banks face competition from foreign banks (GCR), iii Extension of credit: Percentage of credit extended to private sector, iv Avoidance of interest rate controls and regulations that lead to negative real interest rates, $v$ Interest rate controls: Interest rate controls on bank deposits and/or loans are freely determined by the market (GCR). (2) Source: National sources, ECB calculations. Household debt / real GDP. Household debt comprises total loans to households from all institutional sectors, based on national definitions. 
Table 3: Financial distress due to mortgage and housing costs and the distribution of mortgage debt to income ratio

\begin{tabular}{l|c|c|c|c|c|c}
\hline \multirow{2}{*}{$\begin{array}{c}\text { Housing costs } \\
\text { are a heavy } \\
\text { burden }\end{array}$} & \multicolumn{5}{|c}{ Mortgage Debt to Income Ratio } \\
\cline { 3 - 7 } & $25^{\text {th }}$ percentile & Median & $75^{\text {th }}$ percentile & Mean & SD \\
\hline FI & 0.20 & 0.13 & 0.19 & 0.27 & 0.21 & 0.13 \\
UK & 0.07 & 0.10 & 0.16 & 0.24 & 0.20 & 0.20 \\
DK & 0.07 & 0.13 & 0.19 & 0.27 & 0.22 & 0.16 \\
DE & 0.13 & 0.10 & 0.19 & 0.29 & 0.22 & 0.20 \\
NL & 0.01 & 0.12 & 0.18 & 0.26 & 0.20 & 0.16 \\
BE & 0.21 & 0.11 & 0.16 & 0.22 & 0.19 & 0.16 \\
FR & 0.19 & 0.14 & 0.20 & 0.27 & 0.22 & 0.15 \\
AT & 0.12 & 0.03 & 0.08 & 0.17 & 0.13 & 0.19 \\
IT & 0.47 & 0.10 & 0.18 & 0.29 & 0.23 & 0.22 \\
ES & 0.42 & 0.12 & 0.19 & 0.29 & 0.24 & 0.21 \\
PT & 0.33 & 0.09 & 0.18 & 0.29 & 0.22 & 0.22 \\
GR & 0.32 & 0.03 & 0.08 & 0.16 & 0.13 & 0.19 \\
& & & & & & \\
All & 0.17 & 0.11 & 0.18 & 0.26 & 0.21 & 0.18 \\
\hline
\end{tabular}

Note: Source: Weighted statistics from the ECHP pooled sample of households with a mortgage outstanding from the years 1994-2001 (excluding those with more than 75 years old head or DSR in excess of 3 ). 


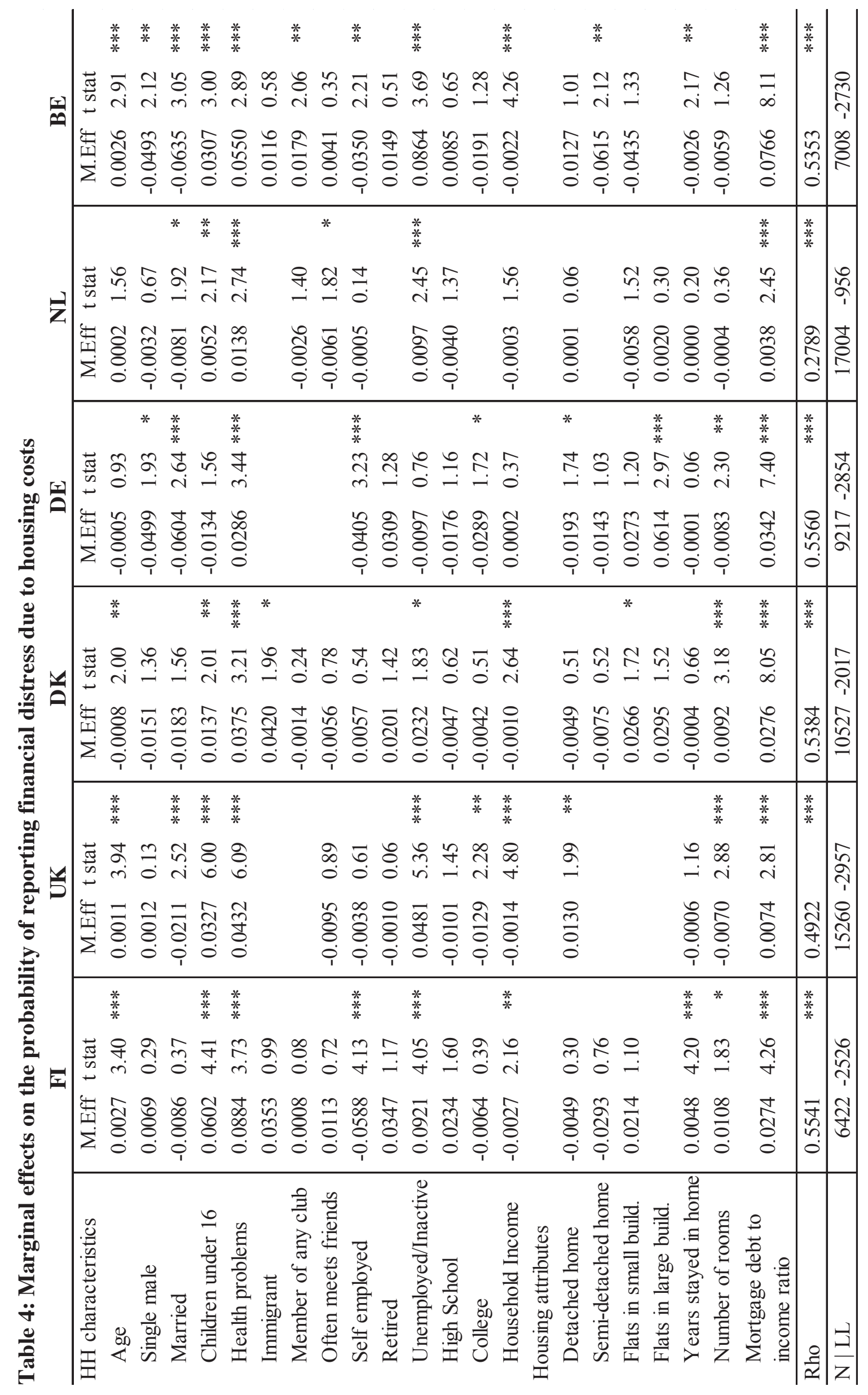




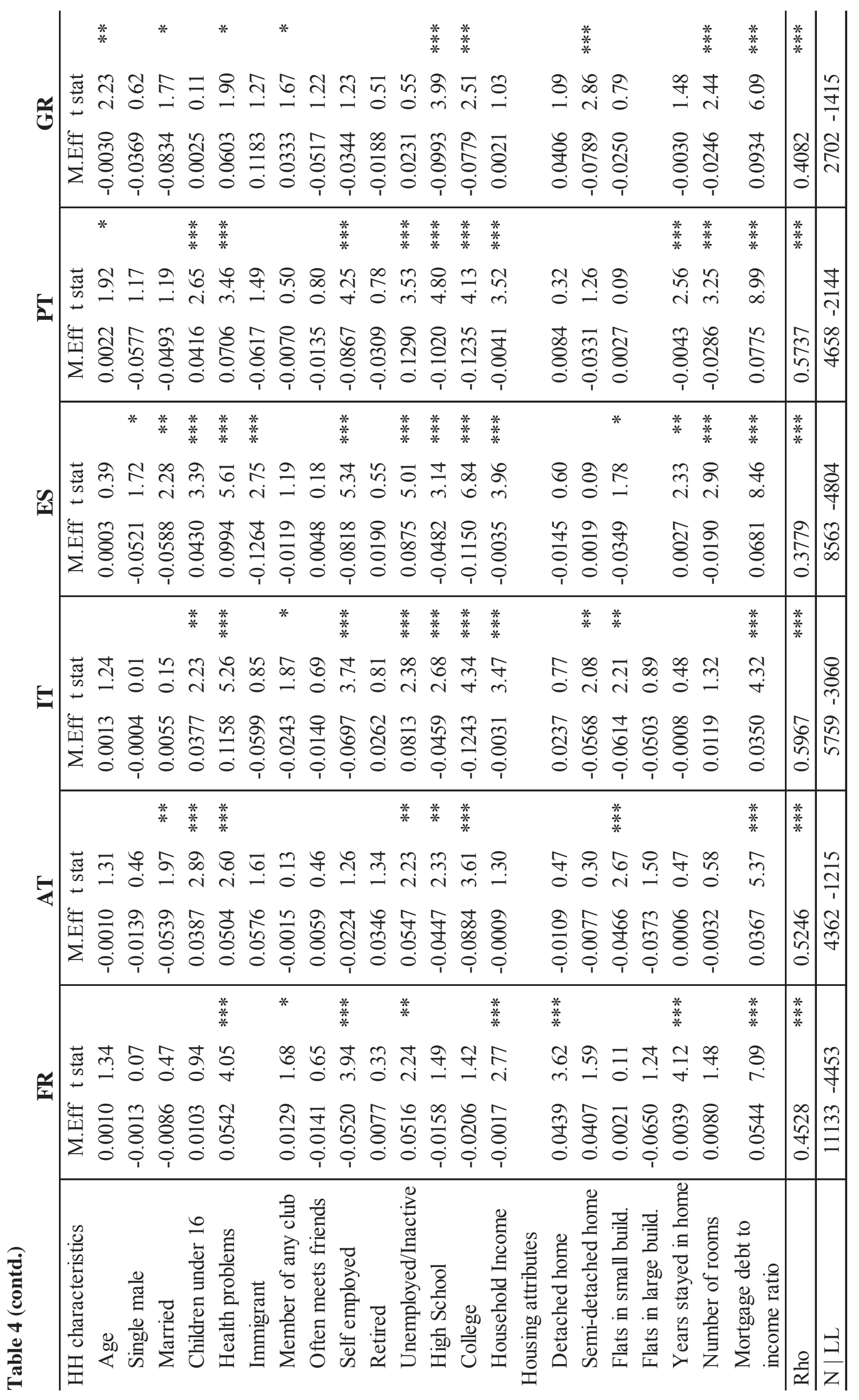


Note (Table 4): Random Effects Probit regressions with Mundlak adjustment. The specification accounts for age and DSR through a $2^{\text {nd }}$ order polynomial and for income through a logarithmic transformation. It also includes the following terms: time and regional dummies, time averages of the logarithm of income and of DSR and its square. Marginal effects are averaged across households using survey weights. The calculation of marginal effects for DSR is based on a $10 \mathrm{pp}$ increase and for income on a 1000 (ppp-adjusted) monetary units increase in the underlying variables, for house size on one extra room, and for age and for years stayed in the house on a one year increase. $* * * * *, *$ denote significance at $1 \%, 5 \%$ and $10 \%$ respectively. 
Table 5: The effect of own indebtedness and of having a debt burden in excess of that of reference group on reported financial distress

\begin{tabular}{|c|c|c|c|c|c|c|c|c|c|c|}
\hline & \multicolumn{3}{|c|}{$\begin{array}{c}\text { Debt burden above } \\
\text { median of reference } \\
\text { group }\end{array}$} & \multicolumn{3}{|c|}{$\begin{array}{l}\text { Mortgage debt to } \\
\text { income ratio }\end{array}$} & \multirow[b]{2}{*}{$\mathrm{N}$} & \multirow[b]{2}{*}{ LL } & \multirow[b]{2}{*}{ Rho } & \\
\hline & M.Eff & t stat & & M.Eff & t stat & & & & & \\
\hline FI & 0.0431 & 3.30 & $* * *$ & 0.0142 & 1.99 & $* *$ & 6422 & -2521 & 0.55 & $* * *$ \\
\hline UK & 0.0113 & 2.15 & $* *$ & 0.0059 & 2.20 & $* *$ & 15260 & -2955 & 0.49 & $* * *$ \\
\hline DK & -0.0005 & 0.07 & & 0.0278 & 7.43 & $* * *$ & 10527 & -2017 & 0.54 & $* * *$ \\
\hline $\mathrm{DE}$ & 0.0218 & 2.32 & $* *$ & 0.0289 & 5.69 & $* * *$ & 9217 & -2851 & 0.56 & $* * *$ \\
\hline NL & 0.0067 & 3.06 & $* * *$ & 0.0027 & 1.82 & $*$ & 17004 & -952 & 0.28 & $* * *$ \\
\hline $\mathrm{BE}$ & 0.0513 & 4.61 & $* * *$ & 0.0648 & 6.94 & $* * *$ & 7008 & -2720 & 0.53 & $* * *$ \\
\hline FR & 0.0231 & 2.19 & $* *$ & 0.0471 & 5.78 & $* * *$ & 11133 & -4451 & 0.45 & $* * *$ \\
\hline $\mathrm{AT}$ & 0.0323 & 2.69 & $* * *$ & 0.0289 & 4.13 & $* * *$ & 4362 & -1211 & 0.52 & $* * *$ \\
\hline IT & 0.0727 & 4.18 & $* * *$ & 0.0206 & 2.35 & $* * *$ & 5759 & -3052 & 0.59 & $* * *$ \\
\hline ES & 0.0681 & 4.97 & $* * *$ & 0.0544 & 6.93 & $* * *$ & 8563 & -4792 & 0.37 & $* * *$ \\
\hline PT & 0.0835 & 5.28 & $* * *$ & 0.0596 & 6.77 & $* * *$ & 4658 & -2132 & 0.57 & $* * *$ \\
\hline GR & 0.1065 & 4.53 & $* * *$ & 0.0642 & 4.07 & $* * *$ & 2702 & -1403 & 0.39 & $* * *$ \\
\hline
\end{tabular}

Note: Random Effects Probit regressions with Mundlak adjustment. The specification accounts for the same set of regressors as the model of Table 4 and a dummy that takes the value one if the household has a DSR in excess of the median DSR of the reference group (defined on the basis of age-education cells within each country). Marginal effects are averaged across households using survey weights. The calculation of marginal effects for DSR is based on a $10 \mathrm{pp}$ increase in the underlying variable. $* * *, * * *$ denote significance at $1 \%, 5 \%$ and $10 \%$ respectively. 
Table 6: Contract Enforcement

\begin{tabular}{|c|c|c|c|}
\hline \multicolumn{4}{|c|}{ Contract Enforcement Indicators } \\
\hline & $\begin{array}{r}\text { Procedures } \\
\text { (number) }\end{array}$ & $\begin{array}{r}\text { Time } \\
\text { (days) }\end{array}$ & $\begin{array}{r}\text { Cost } \\
(\% \text { of debt })\end{array}$ \\
\hline FI & 32 & 247 & 11.1 \\
\hline UK & 30 & 404 & 21.9 \\
\hline DK & 34 & 380 & 24.6 \\
\hline $\mathrm{DE}$ & 30 & 403 & 14.4 \\
\hline NL & 25 & 514 & 24.4 \\
\hline $\mathrm{BE}$ & 28 & 505 & 16.6 \\
\hline FR & 30 & 331 & 17.4 \\
\hline AT & 27 & 397 & 12.7 \\
\hline IT & 41 & 1,390 & 29.9 \\
\hline ES & 40 & 515 & 17.2 \\
\hline PT & 36 & 577 & 14.2 \\
\hline GR & 39 & 819 & 14.4 \\
\hline
\end{tabular}

Note: Data from Djankov, McLiesh, and Shleifer (2007). 


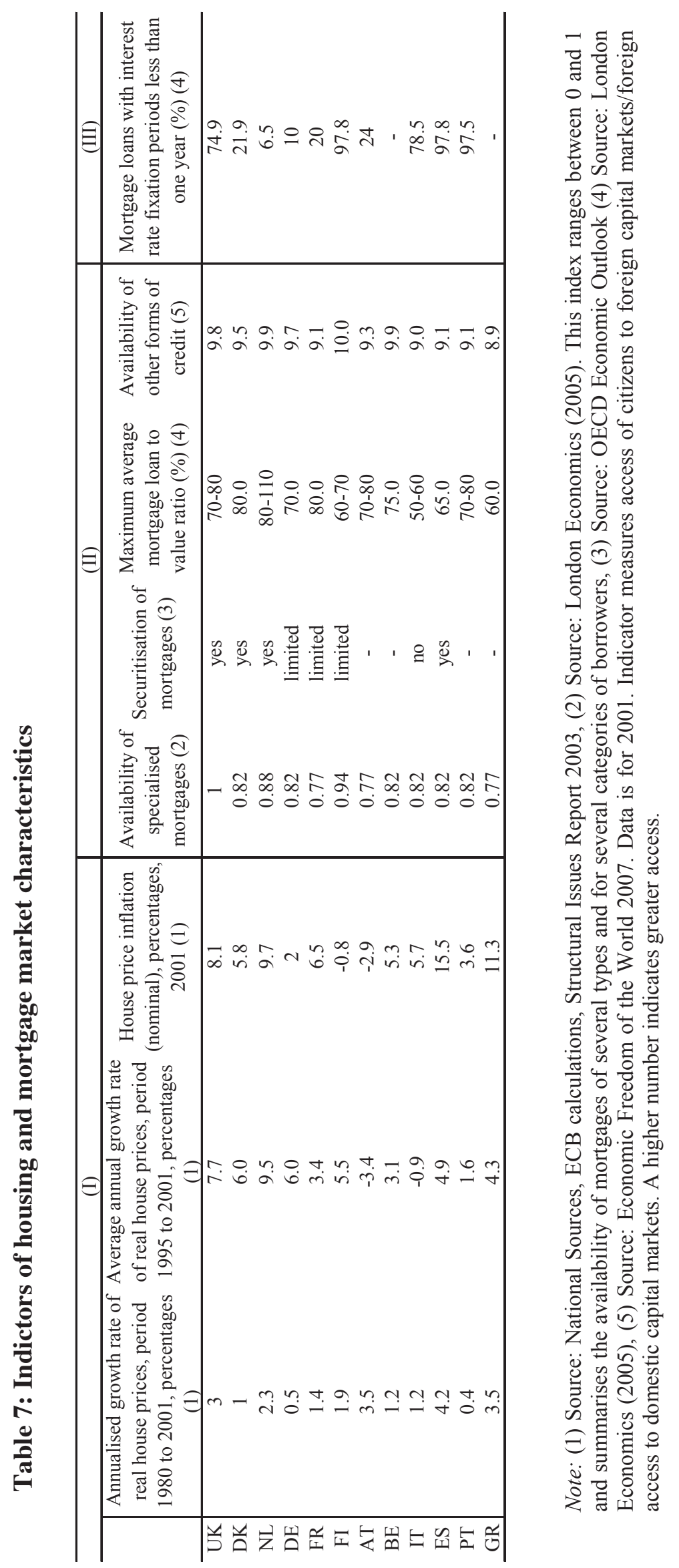




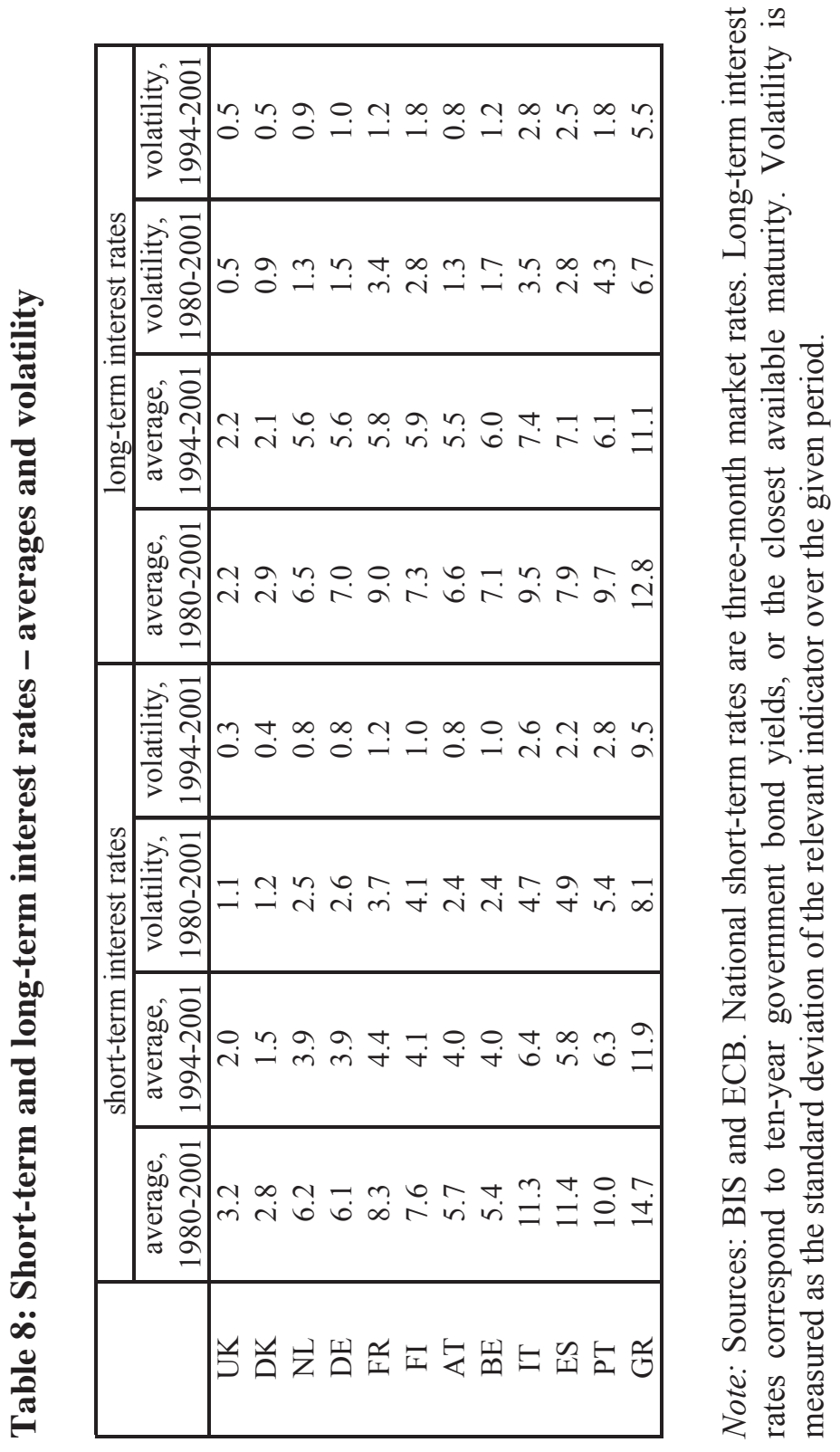


Table 9: Percentage of people who believe that buying on credit is more useful than dangerous

\begin{tabular}{l|cc} 
& All Individuals & Mortgage Holders \\
\hline FI & 32 & 41 \\
UK & 46 & 55 \\
DK & 23 & 22 \\
DE & 22 & 27 \\
NL & 15 & 12 \\
BE & 35 & 37 \\
FR & 36 & 38 \\
AT & 25 & 32 \\
IT & 56 & 61 \\
ES & 65 & 74 \\
PT & 50 & 49 \\
GR & 40 & 38 \\
& & \\
All & 39 & 44 \\
\hline
\end{tabular}

Note: Source: Weighted statistics from Eurobarometer 56.0. 
Figure 1: Predicted probabilities of reported financial distress as a function of mortgage debt to income ratio

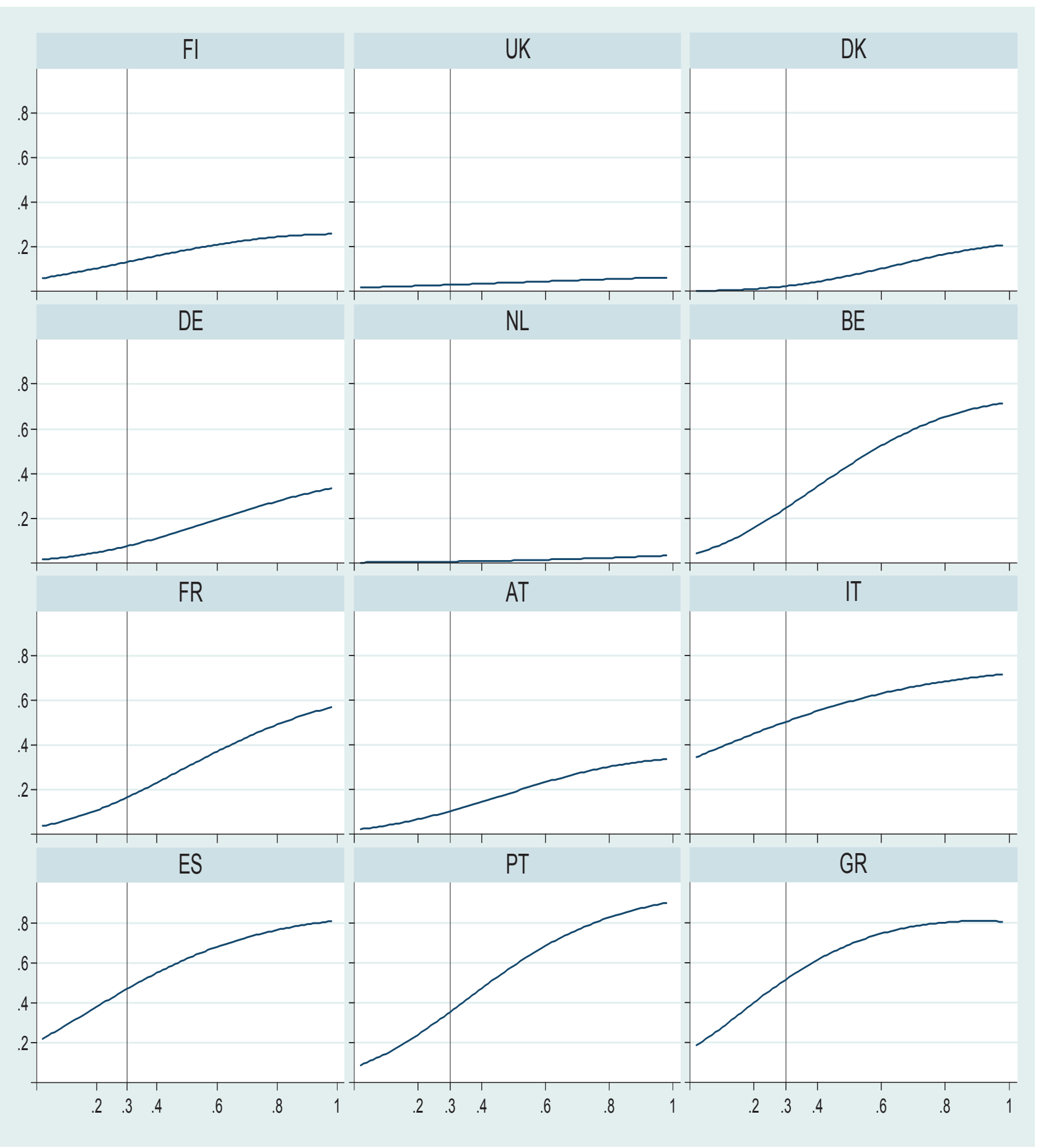

Note: Average predicted probabilities of reported financial distress evaluated at different levels of DSR (derived from the model of Table 4). 


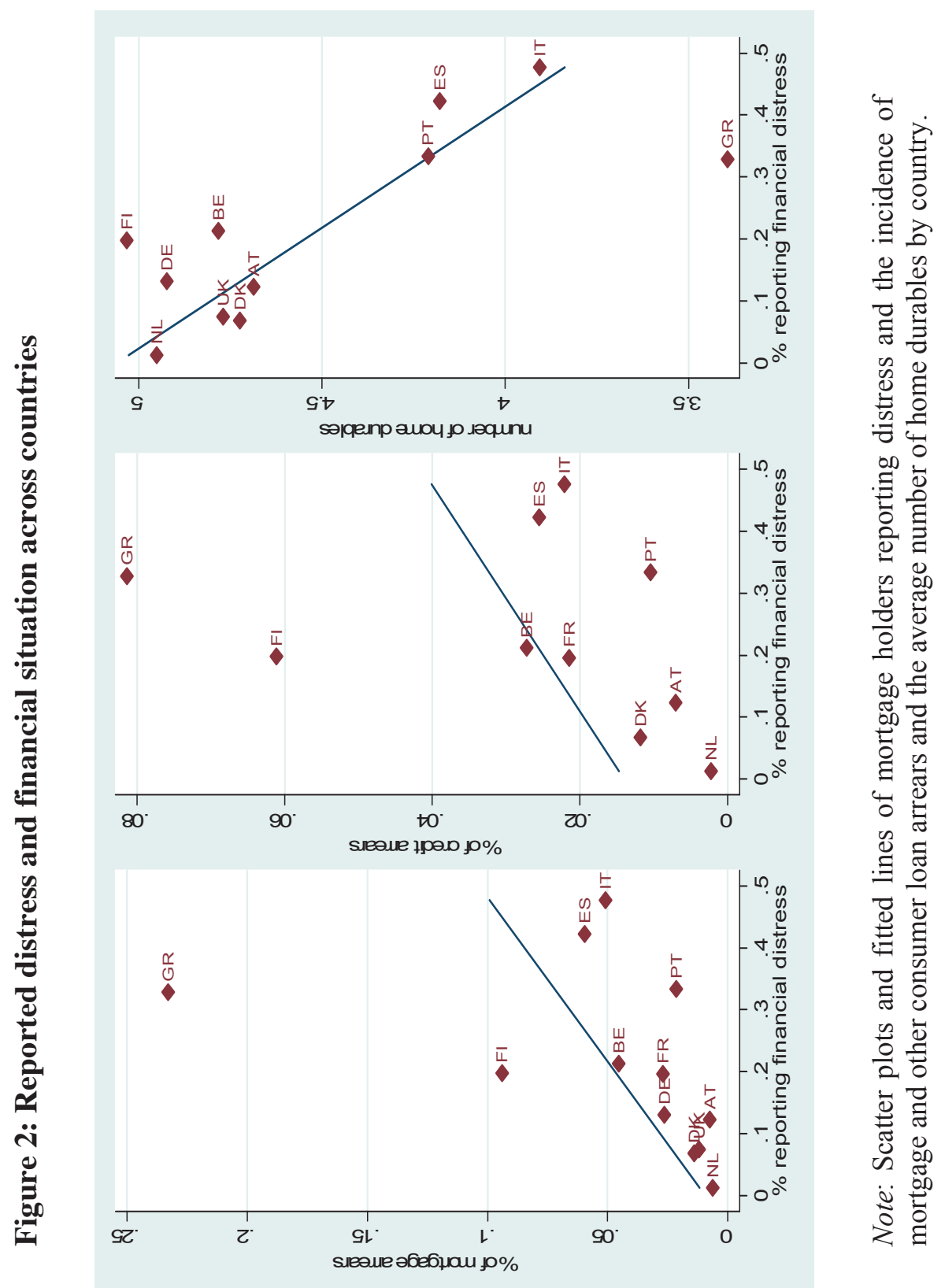




\section{Appendix A}

We perform a series of robustness checks to examine the sensitivity of our findings on the role of relative indebtedness (Section 4, Table 5).

First, we use alternative criteria to construct the cells that comprise households in the reference group. Instead of grouping households on the basis of age and educational attainment we combine information on age and the region of residence within each country. More specifically, within each region in a given country we consider four age bands: 20-29, 30-44, 45-59, and 60-75. In the case of Spain for example, where seven regions are distinguished, the regional-age combination amounts to twenty eight cells. ${ }^{16}$ Then, as in Section 4, we calculate for each regional-age cell the median mortgage debt to income ratio among mortgage holders. Subsequently, in our 'baseline' model (1), we add a dummy indicator that is equal to one if a household has a mortgage debt to income ratio in excess of the median corresponding ratio of its reference group and zero otherwise. Results are shown in Table A1 and paint a similar picture to the one presented in Table 4 (the only exception is the estimated effect of relative indebtedness in Germany which now turns to be insignificant). We have also experimented with other definitions of the reference group by varying the age bandwidth and by combining educational attainment with region of residence and the results are similar to those we present.

As an additional robustness check we define the reference group on a different basis. That is, we consider reference households from the pool of homeowners that comprise both outright home owners and mortgage holders. More specifically, we construct twenty two age-education cells in a similar fashion to our baseline specification (i.e. five-year bands over the age range of our sample combined with more than high school and less than high school educational attainment) among home-owning households in each country. Then for each age-education cell in the pool of home owners we calculate the mean mortgage debt to income ratio. ${ }^{17}$ Next, we add to our baseline

\footnotetext{
${ }^{16}$ Information on regions of residence is not available for households in DK and NL, thus in the current application cells are defined only over age groups in these countries.

17 The respective median is zero in countries where the fraction of outright homeowners exceeds that of mortgage holders.
} 
specification a dummy that represents households with a mortgage debt to income ratio in excess of the mean corresponding ratio of the relevant reference group of homeowners. Table A2 summarizes the results. Having to service a debt above the mean of the corresponding burden of reference home-owning households represents an independent and sizeable source of distress in Spain, Portugal, and Greece, but also in France and Belgium. In sum, results suggest a similar pattern to that derived for reference households that defined over the pool of mortgage holders (with the exception of Italy), providing further support to the role of relative over indebtedness.

Second, we examine the possibility that our dummy representing a debt burden in excess of the median debt load of the reference group simply reflects an effect of excess own indebtedness that is not adequately captured by the DSR term and its square. In the specification we presented in Section 4 we control for non-linearities of both own income and own DSR. For the former we used a logarithmic transformation, while for the latter (given that is defined as the ratio of mortgage installment over income) a squared polynomial. Here, for robustness we assume the same functional form of own DSR and relative indebtedness to preclude the possibility that the effects that we have identified for the latter are simply due to the different functional form from that of the former.

To that effect we first control for the influence of own DSR with a single dummy that takes the value one if a household's DSR is above the median of the total distribution of DSR and zero otherwise. Results from this specification are presented in panel I of Table A3 and suggest a similar picture to the one derived from the baseline model 1 of Table 4. Having a more than median DSR to service creates higher distress in countries with less expanded mortgage markets, after accounting for ppp-adjusted income levels and a rich set of socioeconomic characteristics and housing attributes.

Then, we add in the above specification a dummy representing a debt burden in excess of the median DSR of the reference group to take into account the effect of the relative indebtedness. ${ }^{18}$ Marginal effects along with their significance on own DSR and on relative overindebtedness are presented in panel II of Table A3. The findings are

\footnotetext{
${ }^{18}$ The reference group is defined the same way as in Section 4 (i.e. by combining information on age and education in each country).
} 
similar to those discussed in Section 4. Having a debt burden in excess of the median of the reference group has an independent and significant effect, net of the effect of own indebtedness (i.e. a more than median DSR), own income, various demographics and housing attributes. In countries where fewer households use mortgage debt the effects of relative indebtedness on reported distress are quantitatively significant and in some cases as high as those implied by the own debt load (e.g. Italy, Spain, Belgium, and Portugal). 
Table A1: The effect of own indebtedness and of having a debt burden in excess of that of reference group on reported financial distress

\begin{tabular}{|c|c|c|c|c|c|c|c|}
\hline & \multicolumn{2}{|c|}{$\begin{array}{c}\text { Debt burden above } \\
\text { median of reference } \\
\text { group }\end{array}$} & \multicolumn{2}{|c|}{$\begin{array}{l}\text { Mortgage debt to } \\
\text { income ratio }\end{array}$} & \multirow[b]{2}{*}{$\mathrm{N}$} & \multirow[b]{2}{*}{ LL } & \multirow[b]{2}{*}{ Rho } \\
\hline & M.Eff & t stat & M.Eff & t stat & & & \\
\hline FI & 0.0366 & $2.57 * * *$ & 0.0166 & $2.16 * *$ & 6422 & -2521 & $0.56 * * *$ \\
\hline UK & 0.0126 & $2.32 * *$ & 0.0057 & $2.05 * *$ & 15260 & -2953 & $0.51 * * *$ \\
\hline DK & 0.0022 & 0.32 & 0.0299 & $7.96 * * *$ & 10527 & -2021 & $0.54 * * *$ \\
\hline $\mathrm{DE}$ & 0.0103 & 1.17 & 0.0319 & $6.14 * * *$ & 9217 & -2852 & $0.56^{* * *}$ \\
\hline NL & 0.0074 & $2.94 * * *$ & 0.0039 & $3.06 * * *$ & 17004 & -954 & $0.28 * * *$ \\
\hline $\mathrm{BE}$ & 0.0402 & $3.59 * * *$ & 0.0663 & $6.78 * * *$ & 7008 & -2723 & $0.53 * * *$ \\
\hline FR & 0.0423 & $3.98 * * *$ & 0.0407 & $4.94 * * *$ & 11133 & -4444 & $0.45 * * *$ \\
\hline AT & 0.0576 & $4.79 * * *$ & 0.0229 & $3.30 * * *$ & 4362 & -1203 & $0.55 * * *$ \\
\hline IT & 0.0463 & $2.79 * * *$ & 0.0264 & $2.90 * * *$ & 5759 & -3056 & $0.59 * * *$ \\
\hline ES & 0.0564 & $4.14 * * *$ & 0.0569 & $6.72 * * *$ & 8563 & -4795 & $0.37^{* * *}$ \\
\hline PT & 0.1035 & $5.97 * * *$ & 0.0564 & $6.08 * * *$ & 4658 & -2125 & $0.57 * * *$ \\
\hline GR & 0.1219 & $5.40 * * *$ & 0.0610 & $3.75 * * *$ & 2702 & -1400 & $0.38 * * *$ \\
\hline
\end{tabular}

Note: Random Effects Probit regressions with Mundlak adjustment. The model accounts for the same set of regressors as the specification presented in Table 4 and a dummy that takes the value one if the household has a DSR in excess of the median DSR of the reference group (defined on the basis of age-regional cells within each country). Marginal effects are averaged across households using survey weights. The calculation of marginal effects for DSR is based on a $10 \mathrm{pp}$ increase in the underlying variable. ${ }^{* * *}, * * *$ denote significance at $1 \%, 5 \%$ and $10 \%$ respectively. 
Table A2: The effect of own indebtedness and of having a debt burden in excess of that of reference group of home-owning households on reported financial distress

\begin{tabular}{|c|c|c|c|c|c|c|c|}
\hline & \multicolumn{2}{|c|}{$\begin{array}{c}\text { Debt burden above } \\
\text { mean of reference } \\
\text { group }\end{array}$} & \multicolumn{2}{|c|}{$\begin{array}{l}\text { Mortgage debt to } \\
\text { income ratio }\end{array}$} & \multirow[b]{2}{*}{$\mathrm{N}$} & \multirow[b]{2}{*}{ LL } & \multirow[b]{2}{*}{ Rho } \\
\hline & M.Eff & t stat & M.Eff & t stat & & & \\
\hline FI & 0.0013 & 0.09 & 0.0264 & $3.50 * * *$ & 6422 & -2525 & $0.56^{* * *}$ \\
\hline UK & 0.0089 & 1.63 & 0.0062 & $2.21 * *$ & 15260 & -2954 & $0.51 * * *$ \\
\hline DK & 0.0061 & 0.90 & 0.0253 & $6.50 * * *$ & 10527 & -2013 & $0.58 * * *$ \\
\hline $\mathrm{DE}$ & 0.0074 & 0.82 & 0.0329 & $6.75 * * *$ & 9217 & -2853 & $0.56^{* * *}$ \\
\hline NL & 0.0077 & $3.42 * * *$ & 0.0029 & $2.00 * *$ & 17004 & -937 & $0.51^{* * *}$ \\
\hline $\mathrm{BE}$ & 0.0339 & $3.08 * * *$ & 0.0685 & $6.97 * * *$ & 7008 & -2726 & $0.54 * * *$ \\
\hline FR & 0.0323 & $3.28 * * *$ & 0.0468 & $5.67 * * *$ & 11133 & -4448 & $0.45 * * *$ \\
\hline $\mathrm{AT}$ & 0.0190 & 1.53 & 0.0328 & $4.52 * * *$ & 4362 & -1212 & $0.55 * * *$ \\
\hline IT & 0.0333 & 1.33 & 0.0343 & $4.13 * * *$ & 5759 & -3059 & $0.60 * * *$ \\
\hline ES & 0.0661 & $3.99 * * *$ & 0.0631 & $7.76 * * *$ & 8563 & -4795 & $0.38^{* * *}$ \\
\hline PT & 0.0981 & $4.95 * * *$ & 0.0713 & $8.05 * * *$ & 4658 & -2132 & $0.58 * * *$ \\
\hline GR & 0.1031 & $3.55 * * *$ & 0.0877 & $5.50 * * *$ & 2702 & -1409 & $0.41 * * *$ \\
\hline
\end{tabular}

Note: Random Effects Probit regressions with Mundlak adjustment. The model accounts for the same set of regressors as the specification presented in Table 4 and a dummy that takes the value one if the household has a DSR in excess of the mean DSR of the reference group of homeowning households (defined on the basis of age-education cells within each country). Marginal effects are averaged across households using survey weights. The calculation of marginal effects for DSR is based on a $10 \mathrm{pp}$ increase in the underlying variable. $* * *, * * *$ denote significance at $1 \%, 5 \%$ and $10 \%$ respectively. 
Table A3: The effect of above median debt burden and relative indebtedness on financial distress

\begin{tabular}{|c|c|c|c|c|c|c|}
\hline & (I) & & & & & \\
\hline & $\begin{array}{r}\text { Debt b } \\
n\end{array}$ & $\begin{array}{l}\text { den above } \\
\text { dian }\end{array}$ & $\begin{array}{r}\text { Debt b } \\
n\end{array}$ & $\begin{array}{l}\text { len above } \\
\text { lian }\end{array}$ & $\begin{array}{l}\text { Debt b } \\
\text { median }\end{array}$ & $\begin{array}{l}\text { len above } \\
\text { reference } \\
\text { up }\end{array}$ \\
\hline & M.Eff & t stat & M.Eff & t stat & M.Eff & t stat \\
\hline FI & 0.0855 & $7.80 * * *$ & 0.0559 & $3.41 * * *$ & 0.0386 & $2.70 * * *$ \\
\hline UK & 0.0222 & $4.72 * * *$ & 0.0127 & $1.89 *$ & 0.0146 & $2.17 * *$ \\
\hline DK & 0.0390 & $7.23 * * *$ & 0.0318 & $3.95 * * *$ & 0.0109 & 1.33 \\
\hline $\mathrm{DE}$ & 0.0741 & $8.68 * * *$ & 0.0492 & $4.35 * * *$ & 0.0393 & $4.24 * * *$ \\
\hline NL & 0.0081 & $3.75 * * *$ & 0.0023 & 0.79 & 0.0081 & $3.06 * * *$ \\
\hline BE & 0.1035 & $9.35 * * *$ & 0.0647 & $5.03 * * *$ & 0.0620 & $4.87 * * *$ \\
\hline FR & 0.0833 & $9.23 * * *$ & 0.0624 & $5.05 * * *$ & 0.0311 & $2.70 * * *$ \\
\hline AT & 0.0733 & $6.03 * * *$ & 0.0433 & $2.85 * * *$ & 0.0422 & $2.97 * * *$ \\
\hline IT & 0.1138 & $6.63 * * *$ & 0.0580 & $3.03 * * *$ & 0.0893 & $4.98 * * *$ \\
\hline ES & 0.1389 & $10.45 * * *$ & 0.0849 & $5.23 * * *$ & 0.0812 & $5.26 * * *$ \\
\hline PT & 0.1595 & $9.26 * * *$ & 0.1024 & $5.19 * * *$ & 0.1068 & $6.28 * * *$ \\
\hline GR & 0.2371 & $9.72 * * *$ & 0.1852 & $6.76 * * *$ & 0.0825 & $3.35 * * *$ \\
\hline
\end{tabular}

Note: Random Effects Probit regressions with Mundlak adjustment. The model of panel I accounts for DSR through a dummy that takes the value one if DSR is above the median of the total distribution of DSR. The rest of regressors (not reported) are the same as those in Table 4. The model of panel II includes in addition to the model of panel I a dummy that takes the value one if the household has a DSR in excess of the median DSR of the reference group (defined on the basis of age-educational cells within each country). Marginal effects are averaged across households using survey weights. $* * * * * *$ denote significance at $1 \%, 5 \%$ and $10 \%$ respectively. 
